\title{
Comment on "Evidence from acoustic imaging for submarine volcanic activity in 2012 off the west coast of El Hierro (Canary Islands, Spain)" by Pérez NM, Somoza L, Hernández PA, González de Vallejo L, León R, Sagiya T, Biain A, González FJ, Medialdea T, Barrancos J, Ibáñez J, Sumino H, Nogami K and Romero C [Bull Volcanol (2014) 76:882-896]
}

\author{
M. J. Blanco ${ }^{1}$ (D) - E. Fraile-Nuez ${ }^{2}$ A. Felpeto ${ }^{3}$ - J. M. Santana-Casiano ${ }^{4} \cdot$ R. Abella $^{3}$. \\ L. M. Fernández-Salas ${ }^{5}$ J. Almendros ${ }^{6}$ V. Díaz-del-Río ${ }^{7}$ - I. Domínguez Cerdeña ${ }^{1}$ \\ L. García-Cañada ${ }^{3}$ - M. González-Dávila ${ }^{4}$ - C. López $^{3}$ • N. López-González ${ }^{7}$. \\ S. Meletlidis ${ }^{1}$ - J. T. Vázquez ${ }^{7}$
}

Received: 12 March 2015 / Accepted: 8 June 2015

(C) Springer-Verlag Berlin Heidelberg 2015

\section{Introduction}

Pérez et al. (2014) report the presence of submarine volcanic activity observed off the western coast of El Hierro Island in June 2012. They present as their main evidence acoustic imaging records, interpreted as showing submarine plumes, and an aerial picture showing white traces on the sea, which are

Editorial responsibility: J.D.L. White

M. J. Blanco

mjblanco@fomento.es

1 Instituto Geográfico Nacional, La Marina 20, 38001 Santa Cruz de Tenerife, Spain

2 Instituto Español de Oceanografía, Centro Oceanográfico de Canarias, Vía Espaldón, dársena pesquera, Parcela 8, 38180 Santa Cruz de Tenerife, Spain

3 Instituto Geográfico Nacional, Alfonso XII, 3, 28014 Madrid, Spain

4 Instituto de Oceanografía y Cambio Global. Parque Científico-Tecnológico Marino, Universidad de Las Palmas de Gran Canaria, Telde, Spain

5 Instituto Español de Oceanografía, Centro Oceanográfico de Cádiz, Muelle de Levante (Puerto Pesquero) Apdo. 2609,

11006 Cádiz, Spain

6 Instituto Andaluz de Geofísica, Universidad de Granada, Granada, Spain

7 Instituto Español de Oceanografía, Centro Oceanográfico de Málaga, Puerto Pesquero, s/n, 29640 Fuengirola, Málaga, Spain interpreted as pyroclastic material. Pérez et al. (2014) state that the superficial deformation, the geochemical changes, the strong seismicity, and what they call "earthquake tremor" also support their conclusions. Despite the fact that Pérez et al. (2014) do not use the word eruption either in the title or in the abstract, in the Discussion section, the authors affirm that the acoustic imaging data and the aerial picture provide sufficient evidence to infer the occurrence of a new submarine pyroclastic eruption and postulate that these plumes were produced by a short-lived eruption involving several jets. We have critically reviewed the content of that article and conclude that the data (some of which is inexactly interpreted or not correctly georeferenced) do not support the existence of a second eruption on the Island of El Hierro. However, there is a clear consensus among the scientific community on the fact that after the end of the submarine eruption close to La Restinga village (about late February-early March 2012) a few different processes of deep magma injection have taken place below the Island of El Hierro and its surroundings (Prates et al. 2013; García et al. 2014; González et al. 2013), being that of JuneJuly 2012 the first and one of the most important ones.

Following we discuss the different arguments exposed along the paper.

\section{Volcanic plumes}

Pérez et al. (2014) reported five "filament-shaped" acoustic signals emanating from the flanks of mounds in the western 